\title{
Evaluation of the Quality of Service Muasalat Oman Company
}

\author{
Ali Khaliah Al Bluish \\ Hussin A.M Yahia
}

\begin{abstract}
Public transportation is one of the significant contributor towards the economic growth and development of a country as it facilitates the movement of people, labour, products and services and raw materials among others. With the increasing competition and options in the public transportation sector, the customers have become highly demands and expect to be served better by the companies. There are many factors affecting the customer perception and the customer satisfaction level considering the public transportation including the quality of the buses, timing and punctuality of the business. The aim of this research is to examine the degree of service quality and customer satisfaction in the transport service industry in Oman, a case on Mwasalat Bus Way Company. The data was collected via the questionnaire distributed among the medium among the travelers. The data collected has been transformed into numerical format for ease of analysis using the SPSS software 23. The researcher has relied on the software for conducting the reliability test, frequency distribution test, cross tabulation and correlation analysis for assessing the potential relationship between different variables of the study. The research finding has indicated that through Urban transportation sector in Oman is focused on offering high quality service to the customers, there is need for the sector to offer additional benefits to reflect their adoption of market trends as in the free Wi-Fi access while travelling, electronic devices charging points and the latest means of payments like over the phone among others.
\end{abstract}

\section{Introduction}

The Public transportation includes all the transport facilities in which the travellers do not make use of the personal means of the transportation for travelling. It includes the buses, taxis, mini buses and training. Public transportation is very important for the people as it offers the opportunity for moving from one location to another (Ojo, 2014). The rising price of the fuel and the shortage of the petroleum products has raised concerns over the impact on the factors on the service quality and customer satisfaction in the public transportation sector. For every sector, irrespective of whether the sector is private or public, the customer satisfaction and maintaining high service quality, has become one of the most significant factor for sustaining competitive advantage (Khurshid et al., 2012). It has been argued that increased investment is being made in the public transport systems to ensure the competitiveness of the sector has maintained against the notably increasing private cars. New services are being deployed and the old one are being constantly improved. Customer satisfaction and quality is the considered as the most important elements irrespective of whether it is product or service. In case of any failure to satisfy the customers, there is always a substitute ready to take over the transportation sector. It has been further argued that there is a direct link between the service quality and the customer's perception of the quality of the services. For the government to cares the use of the public transportation, the service needs to be designed and performed to enhance the quality of services offered to the customers (Nyongesa Murambi and M. Bwisa, 2014).

\section{Customer Service}

Customer service is made of two terms, "customer" and "service". Scott (2013, p29) pointed out to 
the customer platitudes that are focus point for every company and it includes "Our customers are our family", "We are customer driven", "People are our most important asset", "The customer is always right" and "The customer is King". Service is defined as the process that comprises of set of activities that is result of a natural occurrence and interaction with customer and the companies. It is the benefit offered by one party to another (Poor, Poor and Darkhaneh, 2013).

"Customer service is defined as the ability of an organisation to constantly and consistently give the customers what they want and need"

Citing the work of Christopher Lovelock, customer service has been defined as follow:

"Customer service involves task-oriented activities other than proactive selling that involve interactions with the customer in person, by phone or by mail among others. This function is designed, performed and communicated with two goals which includes operational efficiency and customer satisfaction"

(Mishra and Gupta, 2009; p.273).

\section{Service Quality and Customer Satisfaction}

While authors like have argued that there is a strong link between the service and the quality dimensions as determined by Anderson and Sullivan (1993) and cited by (Jamal and Anastasiadou, 2009), there is debate on the role of customer satisfaction in terms of being the antecedent of the service quality judgements made by the customers or whether it is other way around as questioned by (Parasuraman, Zeithaml and Berry, 1985). Malik (2012) stressed that the concept of customer satisfaction is the main outcome of the marketing practices. Satisfaction is the good and service judgement made by the consumers about pleasure and displeasure. Perceived service quality is defined as the consumer's judgment about the business's overall dominance or distinction.

The foundation of the service quality was examined from the perspective of SERVQUAL Model which was proposed by Parasuraman et al (1988) and the technical/functional quality framework proposed by Gronroos (1982). However, it has been determined that SERVQUAL model received a lot of criticism in the past few years considering scholars argued that the model mainly focuses on the functional. Aspects of the service quality (Yong and Bojei, 2014). SERVQUAL models highlights five dimensions of service quality and includes reliability, responsiveness, assurance, empathy and tangibles, responsiveness, assurance and empathy which is are focused on the service process.

\section{Customer Perception of Service Quality}

Customer's perceptions of the service quality are influenced by various factors. Customer's expectations are greatly affected by how they perceive quality part from their needs, experiences and word of mouth communication says (Zeithaml, Berry and Parasuraman, 1993). Factors affecting the perception of the consumers towards the service quality has been discussed below:

\begin{tabular}{|l|l|}
\hline Dimension & Explanation \\
\hline Tangibles & $\begin{array}{l}\text { Look of the facilities, personnel's and communication } \\
\text { systems }\end{array}$ \\
\hline Reliability & Ability of performing the services as promised \\
\hline Responsiveness & $\begin{array}{l}\text { Willingness of the company to help the customers and } \\
\text { providing prompt service }\end{array}$ \\
\hline Competence & $\begin{array}{l}\text { Having the required skills and knowledge to be able to } \\
\text { perform the required service }\end{array}$ \\
\hline Courtesy & Respect, politeness and friendliness of the contact personnel
\end{tabular}




\begin{tabular}{|l|l|} 
& from the company \\
\hline Credibility & $\begin{array}{l}\text { Honesty, Trustworthiness and certainty of the service } \\
\text { provider }\end{array}$ \\
\hline Security & Freedom from any form of risk or doubts \\
\hline Access & Ease of contact and approachability \\
\hline Communication & $\begin{array}{l}\text { How the companies keep the customers informed about the } \\
\text { services }\end{array}$ \\
\hline & \\
\hline
\end{tabular}

Table 1. Factors affecting the perception of the consumers towards the service quality

\section{Service in Public Transport}

The fare price and the quality of the vehicles are indicative of the type and range of the service available to the customers. With the increasing competition, companies have realized that offering high quality service is the best mean of achieving differentiation and add to the competitive edge especially in the transportation sector. Kundi (2013) says in the public transport sector, people provide the services for the passengers. The overall emphasis is placed on the total experience of the customers. From the perspective of the passengers, the service is performance of the owner of the vehicles, their staff and therefore becomes a major aspect of the marketing of the services of the companies. During the service transaction, there is a personal involvement between the passengers and the operator of the bus. The services are offered and received at the same time and therefore experience becomes a vital element of the transaction. Citing the work of Powers and Barrows (1994), the researcher stresses that for being a successful bus operator, it is vital to develop a service culture that is based on commitment, trust, high standard of practice and a welldeveloped communication systems.

\section{Data collection}

Dümke (2002) cited the work of Saunders et al and noted that the data collection is the fifth stage in the research wherein the necessary data is collected and analysis for finding solution to the research questions. The data in research has been collected in two forms as in the primary data and secondary data.

\section{The secondary data:}

The secondary data is the data that has been previously gathered for some other purpose. The origin of the data within a study determined whether the data is primary or secondary in nature (Wrenn, Stevens and Loudon, 2007). Secondary data are those data that have already been collected and summarized and collected for some other purpose other than the research project at hand. Considering the advantages and disadvantages of the secondary data, it has been noted that it is a very cost-effective method and the data can be gathered rather quickly in comparison to the primary data. Conversely, the secondary data's reliability, accuracy and credibility is not known and available data might not be presented in the usable format. In this study, the secondary data in this research study has been collected from books, scholar articles, industry publications and internet sources among others.

\section{The primary data}

The primary data is defined as those data that has been collected for the first time by the researcher for a specific research project at hand (Wrenn, Stevens and Loudon, 2007). Goodwin (2012) says the collection of the primary data is the responsibility of the researcher. The researcher s responsible for designing collecting a summarizing the desired data in addition to determining the measurement instruments that will be used in the research. Considering the advantages and 
disadvantages of the primary data, it was noted that it helps in addressing the specific research questions, there is greater degree of reliability, accuracy and credibility and can help in addressing any type of research questions. Conversely, the collection and analysis of the can be expensive and time consuming as well as required the researcher to have the necessary skills for conking the primary data collection (Morgan and Summers, 2005).

\section{Sampling and target population:}

As evident from the research project, the target population in this study are the passengers/travelers of the transportation services. As the bus company services over 3 million travelers it is practically impossible for the researcher to conduct the survey among entire target population. Therefore, considering the feasibility and availability of the time, a sample size of 200 passengers was chosen using the random probability sampling method. Random probability sampling method has allowed the researcher to gather opinion of from the passengers irrespective of whether they hold Omani nationality or not.

\section{Results and discussion}

In order to assess the reliability, the researcher conducted the reliability analysis to determine the Cronbach's alpha value. According to Cronbach's Alpha is the method used for measuring the internal consistency or the reliability in terms of Cronbach's Alpha coefficients. It reflects the correlation between the items responses used in the questionnaire (Andrew, Pedersen and McEvoy, 2011). As evident in the above figure, the internal consistency can be interpreted based on the Cronbach's Alpha value.

\section{Reliability Statistics}

\begin{tabular}{|l|l|}
\hline $\begin{array}{l}\text { Cronbach's } \\
\text { Alpha }\end{array}$ & $\mathrm{N}$ of Items \\
\hline .814 & 18 \\
\hline
\end{tabular}

Figure 1.

Considering the results presented in the above table it can be determined that the Cronbach's Alpha value is 0.814 . This indicates that the internal consistency is good. Furthermore, the statistical significance (p) is lesser than 0.05 indicating that the researcher has received statistically significant results.

\begin{tabular}{|l|l|l|l|}
\hline \multirow{2}{*}{ Variables } & Category & \multicolumn{2}{|c|}{ Results } \\
\cline { 2 - 4 } & & F & $\%$ \\
\hline \multirow{3}{*}{ Sender } & Male & 100 & 50 \\
\cline { 2 - 4 } & Female & 100 & 50 \\
\hline \multirow{5}{*}{ Age Group } & Omani & 65 & 28 \\
\cline { 2 - 4 } & Non-Omani & 144 & 72 \\
\hline \multirow{5}{*}{ Education } & $18-25$ years old & 51 & 25.5 \\
\cline { 2 - 4 } & $26-33$ years old & 61 & 30.5 \\
\cline { 2 - 4 } & $34-41$ years old & 53 & 26.5 \\
\cline { 2 - 4 } & $>=42$ years old & 35 & 17.5 \\
\hline & Intermediate & 53 & 26.5 \\
\cline { 2 - 4 } & Secondary & 60 & 30 \\
\cline { 2 - 4 } & University level & 87 & 43.5 \\
\hline
\end{tabular}




\begin{tabular}{|l|l|l|l|}
\hline Occupation & Government employees & 76 & 38 \\
\cline { 2 - 4 } & Business men & 44 & 22 \\
\cline { 2 - 4 } & Retired person & 13 & 6.5 \\
\cline { 2 - 4 } & Students & 67 & 33.5 \\
\hline
\end{tabular}

Table 2. Respondents profile

\section{Perspective of the passengers on the quality of the service}

\section{There is sufficient number of buses route to and from Muscat regions and suburbs.}

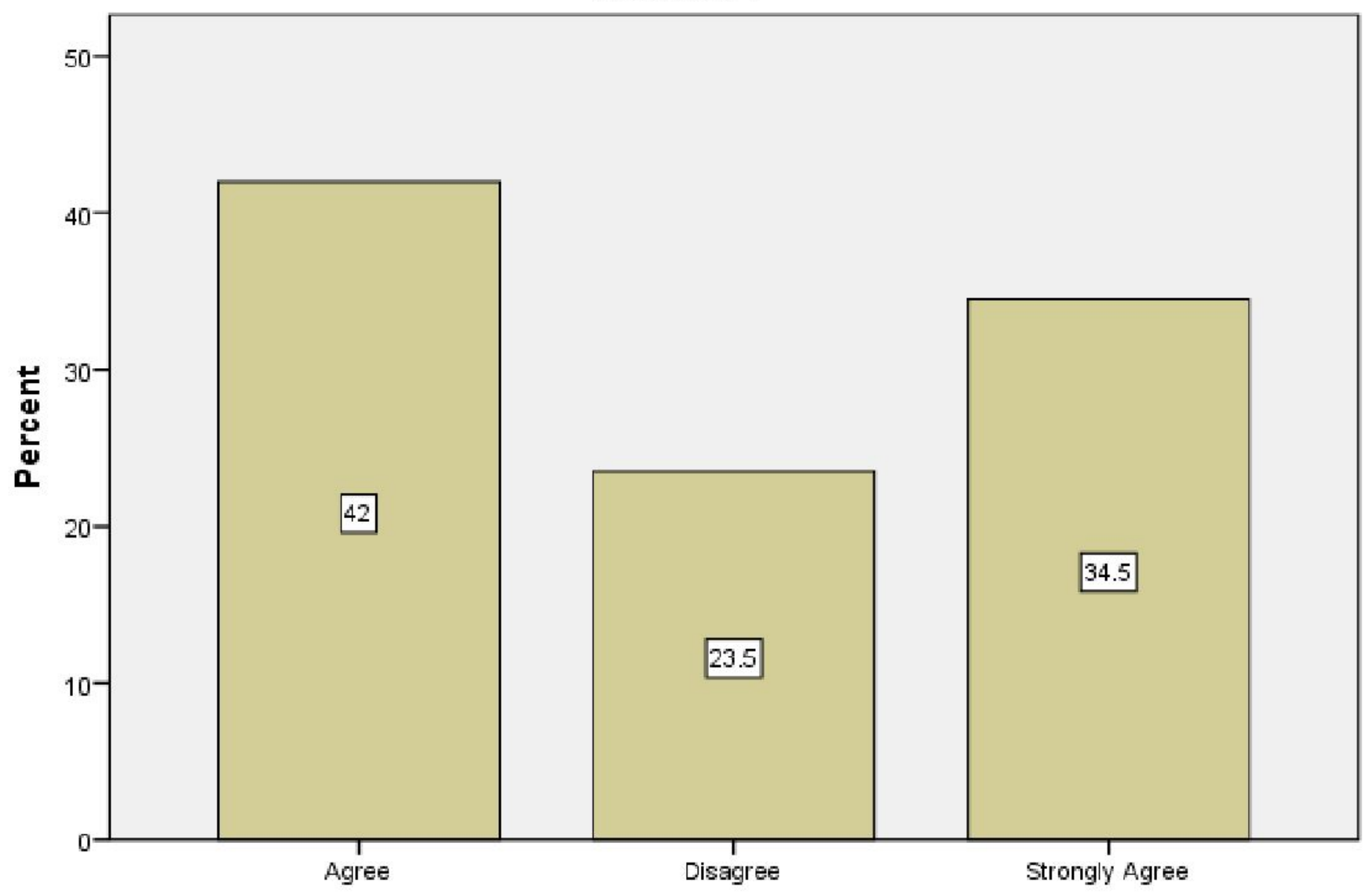

There is sufficient number of buses route to and from Muscat regions and suburbs.

Figure 2. There is sufficient number of buses route to and from Muscat regions and suburbs

In the above chart, the researcher has presented the findings considering the perspective of the passengers to reflect whether they feel that there are sufficient number of buses route to and from the Muscat regions and suburbs. The findings suggest that $34.5 \%$ of the passengers have strongly agreed and $42 \%$ of the passengers have agreed with the statement as well. However, $23.5 \%$ of the passengers have disagreed suggesting that there is need for increasing the number of buses plying in and around the Muscat regions. The disagreement is aligned with the view of Belwal (2010), who stressed on the lack of sufficient public transportation in the Muscat region. The researcher can assume that the passengers who have expressed their opinion might either be residing in the areas that have more number of buses plying and might also be using private cars. 
Figure 3. the arrival timing of the bus is it convenient

In the above chart, the researcher has presented the findings concerning the opinion of the passengers concerning the arrival timing of the bus being convenient. Based on the findings it has been determined that $34.5 \%$ of the passengers have strongly agreed and $42 \%$ of the have agreed that the bus timings are convenient. However, $23.5 \%$ of have disagreed with the statement. Beirão and Sarsfield Cabral (2007) gave supporting opinion and stated that time uncertainty and long wait time has always been major concerns for the travelers.

Figure 4. there is extra services provided (WiFi, phone payment, point for charging your electronic device)

As evident from the above chart, the researcher has questioned the travelers, about the extra services they have been provided in the bus as in the WiFi, phone payment, and point of charging for electronic devices among others. The finding suggests that while $41.5 \%$ of the passengers have agreed with the statement, overall, $58.5 \%$ of the passengers have disagreed. This finding can be used for exploring the view of Kundi (2013) who had pointed out when it comes to the public transport services, the emphasis should not only be providing quality services but enhancing the overall travel experience of the passengers.

Figure 5. the buses' rotation (time table) is flexible and satisfactory

As presented in the above chart are the perspective of the passengers considering the business rotation time table being flexible and satisfactory. As evident, all the passengers irrespective of the degree of agreement the passengers have stated that they are satisfied with the flexibility of the buses rotation time table.

Figure 6.

In the above chart, it is evident that irrespective of the level of agreement, the travellers have agreed that all the buses have safety standards and measures in terms of availability of fire extinguisher, first aid among others.

Conducting the cross tabulation between the opinion of the customer reflecting the quality of the services against the age group of the travelers, it has bene determined that majority of the travellers between the age of 18-25 years old have found the new public transportation established in Muscat is very satisfactory and sufficient. While it has been found that $41.2 \%$ of the travellers have strongly greed in the age group of $18-25$ years, and $51.4 \%$ from the age of $>=42$ years have agreed that there is sufficient number of buses route to and from Muscat regions and suburbs. It is evident that on an average of $20 \%$, all the travellers from the different age group have also expressed dissatisfaction with the number of buses. it has bene determent that majority of the travellers between the age of 18-25 years old have found the bus route to satisfactory. On an average, a similar percentage was evident in all the age groups indicating their satisfaction with the degree of awareness of the drivers. It is evident that on an average of $20 \%$, all the travellers from the different age group have expressed dissatisfaction on the arrival time of the buses.

\section{Conclusion}

Based on the findings the researcher determined that the customer's perceptions of the service 


\section{Journal of Student Research}

Fourth Middle East College Student Research Conference, Muscat, Sultanate of Oman

quality are influenced by various factors including pricing of product, quality of the buses, knowledge of the route, experience of drivers, facilities and coverage area of the transportation services among others. Furthermore, the finding suggest that the customer perception can have significant impact on the future purchase or travel plans as well as the perceptions of other travellers. Based on the finding it is confirmed that perceptions of the quality of the service tend to vary across different socio-economic groups including age groups and nationality. The outcomes of the primary data have clearly pointed out that while majority of the travellers are highly satisfied with the service quality in the Urban Public Transportation in Oman and hold a positive perception.

The finding stressed that Service quality is significant strategy to satisfy the needs of the customers. The service quality has been defined as the measure of how well the service level delivered to the customers matches the expectations of the customers. The finding suggests that pricing of the tickets and the quality of the vehicles uses are primary indicative of the type and range of the service available to the customers in the transportation industry. The outcomes of the primary data have clearly pointed out that while majority of the travellers are highly satisfied with the facilities and the quality of services they are receiving from the transportation sector, there is still scope for improvement in terms of the punctuality of the busses and the additional facilities offered inside the buses. Overall, findings suggest that Urban public transportation sector has not only emphasizes on the range of services, routes offered to the customers but constantly reflect their focus on maintain high quality standards to maintain customer satisfaction. However, it was also found that there is need for emphasizing on the total experience of the customers. The services are offered and received at the same time and therefore experience becomes a vital element that needs to be part of the transportation strategy for the industry.

As well as the finding has established that there is a direct link between the customer satisfactions in the Urban Public Transportation sector of Oman however, there are numerous variables that affect this relationship. The factors include the quality of buses, timing of the buses, experience and knowledge of the operators and drivers, the facilities offered to the travellers and the areas and regions that are covered by the transportation systems among others. Customer satisfaction has emerged as the antecedent of the service quality judgements made by the customers. The study of the SERVQUAL model has enabled the researcher to determine the factors or elements that outline the service quality of a service. It was found that the service quality is significant strategy to satisfy the needs of the customers and encourage them towards repeated service which helps in building a loyal customer base in the public transportation sector.

\section{Acknowledgements}

The research was conducted in collaboration with the Department of Civil Engineering, Middle East College/ Knowledge Oasis Muscat, Oman

\section{References}

Al-Rawas, M (1989). Urban transportation problems in the Muscat area, Sultanate of Oman. PhD thesis, University of Salford.

Andrew, D., Pedersen, P. and McEvoy, C. (2011). Research methods and design in sport management. Champaign, IL: Human Kinetics.

Arsanam, P. (2014). The Relationship between Service Quality and Customer Satisfaction of Pharmacy Departments in Public Hospitals. International Journal of Innovation, Management and Technology, 5(4).

Beirão, G. and Sarsfield Cabral, J. (2007). Understanding attitudes towards public transport and private car: A qualitative study. Transport Policy, 14(6), pp.478-489. 


\section{Journal of Student Research}

Fourth Middle East College Student Research Conference, Muscat, Sultanate of Oman

Eboli, L. and Mazzulla, G. (2007). Service Quality Attributes Affecting Customer Satisfaction for Bus Transit. Journal of Public Transportation, 10(3), pp.21-34.

Dümke, R. (2002). Corporate Reputation and its Importance for Business Success: A European. diplom.de.

Fellesson, M. and Friman, M. (2012). Perceived Satisfaction with Public Transport Service in Nine European Cities. Journal of the Transportation Research Forum, 47(3).

Friman, M., Edvardsson, B. and Gärling, T. (2001). Frequency of negative critical incidents and satisfaction with public transport services. I. Journal of Retailing and Consumer Services, 8(2), pp.95-104.

Gatersleben, B. and Uzzell, D. (2007). Affective Appraisals of the Daily Commute: Comparing Perceptions of Drivers, Cyclists, Walkers, and Users of Public Transport. Environment and Behavior, 39(3), pp.416-431.

Goodwin, J. (2012). SAGE secondary data analysis. Los Angeles: SAGE.

Graham, J. and Andreasen, A. (1997). Marketing Social Change: Changing Behavior to Promote Health, Social Development, and the Environment. Journal of Marketing Research, 34(2), p.294.

Himanen, V., Lee-Gosselin, M. and Perrels, A. (2005). Sustainability and the interactions between external effects of transport. Journal of Transport Geography, 13(1), pp.23-28.

Hussein A.M Yahia \& Amiruddin Ismail 2013. Causes and effects of road traffic accidents in Tripoli - Libya. Proceeding the 6th Civil Engineering Conference in Asia Region: Embracing the Future through Sustainability. Jakarta, Indonesia ISBN 978-602-8605-08-

Hussin, A.M.Y. and I. Amiruddin, 2011. Traffic accidents in Libya. Proceeding of the International Conference on Traffic Longistic Engineering. Chennai, India.

Hussin A.M. Yahia and Amiruddin Ismail, 2014. Knowledge of Traffic Laws and Drivers Behavior on the Roads of Tripoli City, Libya. Research Journal of Applied Sciences, Engineering and Technology 7(10): 2040-2045, 2014 ISSN: 2040-7459; e-ISSN: 2040-7467.

Hussin A.M Yahia, 2016. Antecedents and Consequences of Car Driver Behaviours towards RTA Involvement using Structural Equation Models (SEM), International Journal of Transportation Systems.

Hussin A.M Yahia 2011, Hussin AM Yahia, Amiruddin Ismail, Traffic Accidents Analysis in Libya, Sustainable Building and Infrastructure Systems: Our Future Today.

Ilieska, K. (2013). Customer Satisfaction Index - as a Base for Strategic Marketing Management. TEM Journal, 2(4).

Ismail, I., Haron, H. and Marimuthu, M. (2014). USM and the APEX journey. 1st ed. Malaysia: Penerbit USM.

Jamal, A. and Anastasiadou, K. (2009). Investigating the effects of service quality dimensions and expertise on loyalty. European Journal of Marketing, 43(3/4), pp.398-420.

Jones, I. and Gratton, C. (2004). Research methods for sports studies. Psychology Press.

Levesque, T. and McDougall, G. (1996). Determinants of customer satisfaction in retail banking. 
International Journal of Bank Marketing, 14(7), pp.12-20.

Lynch, G. and Atkins, S. (1988). The influence of personal security fears on women's travel patterns. Transportation, 15(3), pp.257-277.

Madu, C. (2003). Statistics as easy as 1, 2, 3 with Microsoft Excel for Windows. Fairfield, CT: Chi Publishers.

Mertler, C. (2009). Action research. Los Angeles: Sage.

Morgan, M. and Summers, J. (2005). Sports marketing. Southbank, Vic.: Thomson.

Malik, S. (2012). Customer Satisfaction, Perceived Service Quality and Mediating Role of Perceived Value. International Journal of Marketing Studies, 4(1).

Mishra, A. and Gupta, R. (2009). Customer Service In Retailing. 1st ed. New Delhi: John Wiley \& Sons.

Morton, C., Caulfield, B. and Anable, J. (2016). Customer perceptions of quality of service in public transport: Evidence for bus transit in Scotland. Case Studies on Transport Policy, 4(3), pp.199-207.

Nkurunziza, A., Zuidgeest, M., Brussel, M. and van Maarseveen, M. (2012). Modeling Commuter Preferences for the Proposed Bus Rapid Transit in Dar-es-Salaam. Journal of Public Transportation, 15(2), pp.95-116.

Nyongesa Murambi, D. and M. Bwisa, P. (2014). Service Quality and Customer Satisfaction in Public Transport Sector of Kenya: A Survey of Shuttle Travelers in Kitale Terminus. International Journal of Academic Research in Business and Social Sciences, 4(9).

Odufuwa, B. (2001). Gender Differentiation in travel behaviour of motorcycle riders in 14 Nigeria Cities. A case study of Ijebu-Ode and Lagos. Long Essay of Geography and Regional Planning. Olabisi Onabanjo University.

OJo, T. (2014). Service Quality and Customer Satisfaction of Public Transport on Cape Coast-Accra Route, Ghana. Developing Country Studies, 4(18).

Pakdil, F. (2014). Improving service quality in highway

Parasuraman, A., Zeithaml, V. and Berry, L. (1985). A Conceptual Model of Service Quality and Its Implications for Future Research. Journal of Marketing, 49(4), p.41.

Pedraja Iglesias, M. and Jesus Yagüe Guillén, M. (2004). Perceived quality and price: their impact on the satisfaction of restaurant customers. International Journal of Contemporary Hospitality Management, 16(6), pp.373-379.

Poor, M., Poor, M. and Darkhaneh, M. (2013). The Quality of Service and Its Importance in Service Organizations. Oman Chapter of Arabian Journal of Business and Management Review, 3(3), pp.34-37. 